10. Mass Culture: Contemporary Western Studies. (2005). (Zverev, V. V., Trans.). Moscow [in Russian].

11. Moshnayga, E. V. (2005). International Cultural Tourism as a Factor of Intercultural Communication. Nauchnye trudy Moscowskogo Humanitarnogo Universiteta, 55, 128-147 [in Russian].

12. Nikulina, O.V. \& Yakunina, Yu. K. (2013). Innovative Technologies in the Field of Tourism Development in Russia and Abroad. Ekonomicheskii analis: theoria and practika, No. 9 (312), 49-59 [in Russian]. Russian].

13. Pine, J.-B. \& Gilmore, J.-H. (2006). The Experience Economy. Moscow-St. Petersburg-Kyiv: Williams [in

14. Skripko, T. O. (2017). Tendencies of Public Development and their Influence on the National Tourist and Recreational Industry. Proceedings of the International Scientific and Practical Conference. Strategic Priorities of Development of Internal Trade of Ukraine on Innovative Bases, Lviv, November 2-3, 2017. (pp. 55-56). Lviv: LTTEU[in Ukrainian].

15. Slivinska, A. (2017). Innovative Tourism: the Search for Existentialism of Being. Proceedings of the International Scientific and Practical Conference. Cultural and Creative Industries: History, Theory and Modern Business: International Business. Kyiv, April 24, 2017. (pp. 126 - 131). Kyiv : NAKKKiM [in Ukrainian].

16. Spiridonova, E. P. (2017). The Power of Visual Formation of Modern Social Paradigms. Vestnyk Saratovskogo Gossudarstvennogo socialno-economicheskogo universiteta, 4 (68), 148-151 [in Russian].

17. Sushchinskaya, M.D. (2012). Deployment of Models of Tourism of Impressions in Cultural Tourism. Izvestiya SPb GEU, 2. Retrieved from https://cyberleninka.ru/article/n/razvitie-modeli-turizma-vpechatleniy-vulturnom-turizme (accessed: 02/09/2018) [in Russian]. [in English].

18. Kotler, P. (1984, October). Dream Vacations: The Stormy Market of Developed Experience. Futurist, 7-13 English].

19. Poon, A. (1993). Tourism, Technology and Competition Strategies. New York: CAB International [in

20. Raj, A. (2007). A New Age of Tourism - and a New Tourist. - Institute of Tourism and Hospitality. Jhansi. Retrieved from http://www.indianmba.com/ Faculty_Column / FC565.html (Release Date: 08/11/2018) [in English].. English].

21. Richards, G. (2001). Cultural Monuments and European Tourism. Wallingford: CAB International [in

22. Skitovsky, T. (1992). The Joyless Economy: the Psychology of Human Satisfaction. Redaction. New York: Oxford University Press [in English].

23. Wilms, J. (2007). Future Trends in Tourism - Global Perspectives - The Future of TOURISM, Proceedings of Amsterdam Club Conference. May 31, 2007 Amsterdam [in English].

Стаття надійшла до редакиії 4.09.2019

Прийнято до публікайї 1.01.2019

УДК165.9:130.2

\author{
Савченко Анжеліка Анатоліївна, \\ кандидат культурології,
} суддя господарського суду Харківської області

ORCID 0000-0002-4875-7884

angelikasavch@gmail.com

\title{
ІСТОРИЧНІ ВИМІРИ ПРАВОВОЇ КУЛЬТУРИ: КОНЦЕПТУАЛЬНИЙ АСПЕКТ
}

\begin{abstract}
Мета статті полягає в дослідженні історичного виміру правової культури як культурно-історичного процесу, складної мережі людських взаємовідносин, які в процесі життєдіяльності керуються певними соціокультурними та правовими нормами й правилами. Методологія дослідження грунтується на застосуванні історичного, культурологічного, міждисциплінарного методів, що дало змогу дослідити історичні виміри правової культури як важливий чинник формування системи соціально-правових відносин у суспільстві та окреслити проблематику правової культури в історичному контексті. Наукова новизна роботи полягає в тому, що автором здійснено спробу обгрунтувати історичні виміри правової культури як відображення досвіду життєдіяльності людства, сформованого за допомогою діяльності людини в соціумі. Висновки. Правова культура має історичний вимір, відображує в собі досвід життєдіяльності людства, сформований 3 допомогою діяльності людини в соціумі, поєднанню зовнішнього та внутрішнього факторів їі формування (зовнішній суспільство, внутрішній - людина, іiі внутрішній, індивідуальний досвід, самореалізація). Зокрема, людина через свою діяльність впливає на систему соціально-правових відносин, а соціум так само вбирає в себе все
\end{abstract}

(C) Савченко А.А., 2019 
найкраще, акумулюючи досвід та формуючи систему соціально-правових відносин у суспільстві, передаючи напрацьовані норми та правила поведінки наступним поколінням.

Ключові слова: культура, правова культура, суспільство, соціум, людина, культурно-історичний процес.

Савченко Анжелика Анатольевна, кандидат культурологии, судья хозяйственного суда Харьковской области

\section{Исторические измерения правовой культуры: концептуальный аспект}

Цель статьи заключается в исследовании исторического измерения правовой культуры как культурноисторического процесса, сложной сети человеческих взаимоотношений, которые в процессе жизнедеятельности руководствуются определенными социокультурными и правовыми нормами и правилами. Методология исследования основана на применении исторического, культурологического, междисциплинарного методов, что позволило исследовать исторические измерения правовой культуры как важный фактор формирования системы социально-правовых отношений в обществе и обозначить проблематику правовой культуры в историческом контексте. Научная новизна работы заключается в том, что автором предпринята попытка обосновать исторические измерения правовой культуры как отражение опыта жизнедеятельности человечества, сформированного посредством деятельности человека в социуме. Выводы. Правовая культура имеет историческое измерение, отображает в себе опыт жизнедеятельности человечества, сформированный посредством деятельности человека в социуме, сочетания внешнего и внутреннего факторов ее формирования (внешний - общество, внутренний - человек, его внутренний, индивидуальный опыт, самореализация). В частности, человек своей деятельностью влияет на систему социально-правовых отношений, а социум, в свою очередь, вбирает в себя все лучшее, аккумулируя опыт и формируя систему социально-правовых отношений в обществе, передавая наработанные нормы и правила поведения следующим поколением.

Ключевые слова: культура, правовая культура, общество, социум, человек, культурно-исторический процесс.

\section{Savchenko Anzhelika, Ph.D. in Culturology, judge of the Economic Court of Kharkiv region}

Historical measurements of legal culture: conceptual aspect

The purpose of the article is to study historical measurements of legal culture as a cultural and historical process, as a complex net of human relationships, which in the process of life are guided by specific socio-cultural and legal norms and rules. The methodology of the study is based on applying of the historical, culturological, crossdisciplinary methods, which allow the author to study historical measurements of legal culture as an essential factor of the formation of the system of social and legal relations within society and outline the problematics of legal culture in historical context. The scientific novelty of the work lies in the author's attempt to ground historical measurements of legal culture as a reflection of the experience of humanity's life activity, which is formed by human activity in society. Conclusions. Legal culture has historical measurements. It mirrors the experience of humanity's life activity, which is formed by human activity in society, by the combination of external and internal factors of its formation (external society, internal - human, his or her internal, individual experience, self-realization). In particular, human influences the system of social and legal relations by his activity, and society, in its turn, absorbs all the best, while accumulating experience and forming a system of social and legal relations in society and delivering developed norms and rules to the next generations. The development of a legal culture is directly related to the general level of culture, the worldviews dominant in the society, the mentality, the monotonous mass behavior of people, the dialogue of cultures and peoples, borrowing from different legal cultures of the new and perspective. Legal culture has perspectives in a society in which the essential elements of the law are produced. Without the level of development of the culture of society, its willingness to accept certain values, and normative guidelines, it is impossible to form a society of developed legal culture and to build the rule of law, which is the topic of further research.

Key words: culture, legal culture, society, society, human, cultural and historical process.

Постановка проблеми. Культура суспільства діалектично поєднує в собі нові та традиційні цінності та є результатом спільної діяльності багатьох поколінь людей, завдяки активним перетворювальним діям яких формується соціум, його соціальні, політичні й культурні інститути, цінності, культурні та правові норми. За таких умов саме правова культура втілює в собі здобутки суспільства в галузі культури, захисту прав та свобод людей, формуючи ціннісно-нормативні уявлення, які відображаються у правосвідомості людей і їх поведінці в соціумі, постає певним соціальним і правовим орієнтиром, забезпечуючи при цьому свідому культурну соціально-правову активність, дотримання в суспільстві належного рівня законності та правопорядку. Правова культура розглядається як складова частина людської культури, що, зокрема, включає в себе правові знання, правову поведінку, діяльність людини в різних сферах суспільства. Водночас історія правової культури певних сфер суспільства є недостатньо дослідженою. Таким чином, видається актуальним дослідити історичні виміри правової культури як специфічного, складного соціального та правового явища. 
Аналіз останніх досліджень і публікацій. Правова культура містить в собі накопичені людством цінності, є єдиним цілим, різноманітні частини якого відображають результат людської діяльності, історичного процессу та людського досвіду. Правову культуру розглядають як складне і багатогранне явище культурно-історичного процесу, що відображує в собі досвід багатьох поколінь для створення гармонійного розвитку людини в суспільстві. Системні дослідження правової культури, які проводили в XX столітті Є. Аграновський, П. Баранов, В. Казімірчук, Д. Керімов, М. Кейзеров, В. Кудрявцев, С. Лукашев, Г. Муромцев й ін., дозволили по-новому поглянути на зміст і структуру правової культури в системі соціальних інститутів та зрозуміти ступінь життєздатності запозичених з минулого різновидів правової культури.

Правова культура як сполучення духовних i матеріальних цінностей відображена в різнопланових працях О. Дьоміної, А. Вебера, А. Венгерова, І. Голосніченко, Н. Гранат, В. Калинської, В. Копєйчикова, В. Лемака, Н. Оніщенко, О. Петришина, М. Рязанова, В. Сальникова, О. Скакун, Т. Синюкової й ін. Уроботах показано, що правова культура, будучи соціальним явищем, формою гармонійного розвитку людини, є неможливою без людини, іiі діяльності, прогресивної спрямованості цієї діяльності та нового мислення $[1 ; 8]$. Відзначено, що через правову культуру, як глобальну форму, відображається певна своєрідність й цінність національних правових ознак: державності, правової системи, правопорядку, де історично закладений «генетичний код» вітчизняних юридичних явищ [9]. Наявність розмаїття правових культур та певних національних характеристик свідчить про їі складність та неоднозначність для пізнання, визначення відповідного статусу та є темою численних дискусій, різних наукових поглядів, що вимагає ретельних досліджень.

Мета статті. Дослідити історичний вимір правової культури як культурно-історичний процес, як складну мережу людських взаємовідносин, які в процесі життєдіяльності керуються певними соціокультурними та правовими нормами і правилами.

Виклад основного матеріалу дослідження. Перш ніж перейти до розгляду заявленої тематики, відзначимо, що сучасному стану науки про культуру властива певна ступінь невизначеності. Культура за споконвічним змістом слова належить до роду «штучного», тобто того, що, на відміну від природи, саме по собі не існує, а створено безпосередньо людьми. Відповідно до цього цілком обгрунтованим виглядає припущення того, що й пізнаватися вона повинна як результат діяльності людини [7].

Вивчення людської діяльності в її найрізноманітніших проявах дозволило сформувати науку про культуру - культурну антропологію [6;12]. Як самостійна дисципліна культурна антропологія, що сформувалася в кінці XIX - на початку XX століття, насамперед в США, вивчає суспільство й культуру, описує й пояснює соціальні та культурні подібності та відмінності [2]. Однозначної думки про те, чи $є$ культурна антропологія самостійною наукою чи входить до складу соціальної антропології, яка вивчає соціальні структури та взаємодію в цих структурах людей, в зарубіжній і вітчизняній літературі поки що не існує [6;10]. Це пов’язано з тим, що справжній зміст та сутність культури можливо усвідомити лише простежуючи різноманітну діяльність людства протягом усієї його історії.

Культура безпосередньо пов'язана з людиною та породжена ії діями. Культура не може існувати поза людиною, так само як і людина не може існувати поза культурою - культурою певного соціуму. Взаємодіючи з соціумом, людина відчуває на собі його вплив і своєю діяльністю впливає на нього. Слушним у цьому разі є визначення $Є$. А. Орлової про те, що культура - це процес, результат та поле реалізації людських можливостей у поточний період часу $[5,8]$. Власне, саме за допомогою культури людина накопичує й відтворює досвід життєдіяльності, який знаходить відображення у здобутках того чи іншого суспільства протягом усієї людської історії.

Культура існує в формі процесу, є своєрідним продуктом історії, оскільки відображує певний специфічний досвід, отриманий в процесі життєдіяльності. Тобто, поза культурою не може бути ні суспільства, ні будь-якої соціальної спільноти. В цьому разі необхідно виходити з культурноісторичного процесу як першооснови й усі формоутворення культури розглядати як перехідний процес ії стану, що припускає безперервний розвиток буття людини та суспільства.

Якщо розглядати культуру як складну, багаторівневу систему, то вона, з одного боку, постає певним сполученням духовних і матеріальних цінностей, що створювалися людством у процесі суспільно-історичного розвитку. 3 іншого, являє собою безперервну людську діяльність, яка використовує напрацьовані попередніми поколіннями здобутки та цінності, створюючи при цьому інші та передаючи їх наступним поколінням. Саме в такому безперервному обміні знаннями, здобутками, вміннями, навичками, здібностями вбачається історичний сенс правової культури як специфічного соціального атрибуту культурно-історичного процесу розвитку суспільства. 
У цьому зв'язку слід звернути увагу на історичне різноманіття людської діяльності, що дозволяє вважати матеріальну і духовну культури першоосновою для появи правової культури. Зазначимо, що поділ на матеріальну та духовну культури є умовним, оскільки ці дві культури невід'ємні одна від одної, є взаємопов'язаними між собою і впливають одна на одну. Будь-який духовний початок постає досягненням людства лише в разі його втілення в ту чи іншу матеріальну оболонку. На думку В. Шейко, «... духовна культура - це олюднений шар життя, друга, штучно створена людиною природа там, де $\epsilon$ людина, іiі діяльність. Ї̈ї продукти, взаємовідносини між людьми - там і є духовна культура» [11, 111-112]. Отже, до духовної культури можна віднести, зокрема, політичну, педагогічну, художню, релігійну, інформаційну культури і, безумовно, правову культуру. 3 огляду на це культура в загальному розумінні являє собою багатовимірне та цілісне утворення, всі частини якого, взаємодіючи між собою, утворюють такий специфічний соціальний феномен, як правова культура.

Власне, якщо культуру історично співвідносять 3 суспільством, то утворення правової культури слід пов'язувати з людиною, суспільством, соціумом. Тобто, правова культура створюється суспільством і функціонує в соціумі. Фактично суспільство майже завжди ототожнюється зі спільнотою, соціумом і говорячи «суспільство», мається на увазі населення тієї чи іншої країни або регіону чи людство в більш широкому сенсі. Відповідно до цього можна вважати, що правова культура постає атрибутом не суспільства, а соціуму - спільноти, співтовариства, етносу, країни, народу, племені або людини в філософському сенсі. Вона може бути пізнана тільки в зіставленні 3 цілісністю дійсного соціуму (конкретної людини, людства тощо). В такому разі саме людина, спільнота та відповідний соціум можуть бути історичними вимірами правової культури.

Розглянемо цю концепцію докладніше. Термін «соціум» набув поширення від латинського слова «socium», що позначає «загальний». Соціологами цей термін застосовується для позначення групи людей, яких єднають загальні погляди, цінності, історія, традиції, культура тощо. Соціум являє собою природне середовище проживання людини, сукупність людей, поєднаних між собою різними взаємовідносинами, що регулюються певними правилами, звичаями, традиціями, моральноетичними, правовими нормами тощо. В соціумі кожен залежить один від одного з тих чи інших причин, але їх поєднує спільна мета - створення й поліпшення загальних умов існування, якості життя за допомогою спільних дій. Процес становлення, розвитку та самовдосконалення в соціумі починається у дитинстві, з народження та триває протягом усього життя.

Соціуму допомагає зберегтися соціалізація - процес засвоєння людиною соціальних, моральних норм, правил, цінностей для того, щоб вона стала повноцінним членом суспільства 3 можливістю взаємодіяти з іншими в процесі життедіяльності, підтримуючи загальний баланс та рівновагу. Отже, в умовах глобалізації певна спільнота (соціум) застосовує ту систему соціального регулювання, яка історично йому властива. Зауважимо, що держави, які в процесі утворення звернулись до власних культурно-історичних джерел, самостійно визначають напрямок соціокультурного розвитку, розвитку права і державної побудови, зберігаючи при цьому національну ідентичність та самобутність.

Слід зазначити, що в періоди, коли у суспільстві відбуваються трансформації суспільного життя, численні кризи та катаклізми, які несуть в собі зміну цінностей, нормативних установок, соціальних, політичних і правових інститутів, постає питання пошуку правових цінностей, які будуть здатні стати основою формування правового менталітету людей. Проблема полягає в тому, що жодні нововедення й перетворення не здатні внести будь-які позитивні зміни там, де ціннісні регулятори не стали елементом свідомості людини, іiі культури й правової культури, зокрема. Зрештою, саме через правову культуру відтворюються цінності, що містять у собі своєрідність та національне забарвлення.

Відзначимо, що правова культура обумовлена правовими цінностями, уявленнями про належні права й свободи людини. Вона існує та відображується через діяльність, змістом та метою якої $є$ захист прав та свобод членів суспільства, дотримання правопорядку тощо. Поза правовою культурою членів суспільства не може існувати правова культура суспільства, яка фактично $\epsilon$ формою реалізації й самовираження соціокультурної й правової діяльності членів суспільства. Якщо ті чи інші правові уявлення набувають розвитку у відповідному суспільстві, вони постають правовими цінностями, що є невід'ємним елементом правової культури суспільства.

Правова культура включає в себе певні моделі поведінки й дій, пов'язаних, зокрема, із застосуванням правових засобів регулювання суспільних відносин. Правова культура функціонує у взаємодії з політичною, релігійною, моральною, естетичною та іншими видами культури й характеризується рівнем законності й правопорядку в країні, розвиненістю, повнотою й забезпеченістю прав і свобод людини й громадянина, ступенем розвиненості в суспільстві юридичної 
освіти й ін. Тобто, на рівень правової культури впливає загальний стан культури населення, вона цілком залежить від рівня суспільної свідомості, ментальності, стану та дотримання у державі правопорядку [4].

Зауважимо, що право, як елемент правової культури та засіб утвердження у суспільстві загального порядку, почало розглядатись як найбільш ефективний інструмент суспільних перетворень, нормативного та дієвого регулятора суспільного життя. Будучи однією 3 найважливіших цінностей суспільства, право розвивається разом із суспільством, відчуваючи на собі вплив зовнішніх і внутрішніх факторів і регулюючи певним чином суспільні правовідносини. Власне, культура $€$ першоосновою, а право супроводжує, підтримує культуру цього суспільства. 3 погляду на думку А. І. Гусейнова, право постає елементом ціннісно-нормативної системи суспільства, на який покладається завдання впорядкування, адаптування, гармонізації, затвердження суспільних відносин, пом'якшення потенційних протиріч, закладених в суспільній системі [3]. Однак, відкритим залишається питання адаптації, впровадження тих чи інших правових норм i цінностей, їх відповідність рівню розвитку суспільства, менталітету, готовності членів суспільства прийняти ті чи інші настанови цінності в контексті сформованої раніше системи цінностей і моделей поведінки $\mathrm{i}$ відображення в свідомості людей.

У різних культурно-історичних умовах однієї держави або цивілізації зміст права та форми його прояву й самовираження є різними, оскільки сформовані моделі поведінки, стереотипи мислення, вірування, спосіб буття, менталітет різних народів, націй, етносів, традиції на тому чи іншому етапі соціокультурного розвитку значно відрізняються, мають певні особливості. Це обумовлює різноманіття правових культур в історичному контексті протягом усієї людської історії. У цьому разі соціокультурний підхід до розуміння правової культури дозволяє виявити не тільки універсальні цивілізаційні й формаційні детермінанти права, але і його різноманітні зв'язки 3 певними історичними особливостями розвитку того чи іншого суспільства. Соціокультурний підхід визначає необхідність антропологічного повороту в праві і можливість синтезу правових i культурологічних знань для комплексного вивчення правової культури [3].

Виходячи з наведеного, культура регулює організовує діяльність різних сфер культури суспільства 3 допомогою сукупності норм, законів, ідеологічних домінант, правил, традицій, цінностей, які обумовлені певними історичними умовами, що є основою наявних моделей поведінки людей, впорядковуючи таким чином суспільні взаємовідносини й формуючи на їх основі нормативно-регулятивні, правові норми, що діють і застосовуються в цьому суспільстві. За таких умов роль правової культури полягає в тому, щоб у суспільстві підтримувався баланс взаємовідносин за допомогою культивування певних моделей поведінки, цінностей, зокрема правових, що є основою суспільства.

Слід зазначити, що в основі становлення правової культури лежить безліч варіантів іiі розвитку. В одній державі, в залежності від історично сформованих суспільних правовідносин на тому чи іншому етапі розвитку суспільства, правова культура виступає в різних формах і проявах, які закріплюються у свідомості людей і набувають ознак цінностей цього суспільства. Отже, саме цінності формують принципи соціального устрою тієї чи іншої держави, іiї правові норми, правове мислення, правову поведінку та ії правову культуру.

У центрі правової культури завжди перебуває людина, що відображує в собі цінності соціуму. Від того, яка система цінностей у суспільстві набуває розвитку, залежить рівень його правової культури. Якщо в суспільстві буде дотримуватись баланс цінностей людини та соціуму й кожен із членів суспільства робитиме свій внесок у його розвиток та вдосконалювання, це суспільство можна сміливо називати суспільством високої правової культури. Тобто, правова культура втілює в собі напрацьовані у процесі історичного розвитку цінності, які відображують реальний правовий стан цього суспільства, його готовність до розвитку та прийняття чогось нового та прогресивного. Зокрема, для сприйняття нового потрібно, щоб воно було на благо людей, несло в собі позитивні зміни, елементи справедливості, законності, порядку та рівності прав кожного. Розвинена правова культура є немислимою без розвитку в суспільстві права, правосвідомості, правового мислення, правової діяльності, затвердження системи правових цінностей.

Зрештою, правова культура є показником розвитку суспільства, мірою, за якою можливо установити сприйняття та засвоєння накопиченого досвіду та використання його на користь усіх членів суспільства. Будучи елементом культури, право орієнтується на цю культуру, надаючи якісних характеристик розвитку суспільства та рівню його правової культури. Власне, в залежності від складових системи «людина - соціум - суспільство» ми можемо надати характеристику будь-якій правовій культурі, іiі сутнісним рисам. Ці складові формують історію правової культури, надаючи 
можливість простежити іiі історичні виміри. На тому чи іншому етапі історичного процесу правова культура вбирає в себе їхній сутнісний характер та особливості, акумулює та відображує в історичному контексті у вигляді звичаїв, норм, правил, законів тощо.

В залежності від ціннісних настанов, наявних домінант розвитку, акумулюється найкраще та набуває розвитку держава 3 iї устоями, національною окрасою, особливостями. Якщо ціннісні настанови містять в собі певний баланс та взаєморозуміння, вони асимілюються та трансформуються в устояні, норми та правила, що не підлягають сумніву. Якщо вони засновані на страху або примусі діють до його зникнення, оскільки не усвідомлюються як необхідність, і тому, як тільки зникає складова заборон (страху, примусу), у свідомості проявляються інші, ті, що існують на підсвідомому рівні. Виходячи 3 наведеного, правова культура в ціннісно-змістовному аспекті постає певною нормативною системою, що містить у собі сукупність усіх цінностей, які були створені людьми у сфері права протягом людської історії. Якщо узяти за основу комплексну систему «культура - право - суспільство - соціум», то правова культура в іiі загальному вигляді, що є похідною від цієї системи, включає в себе елементи усіх їі складових у їхньому історичному вимірі та безліч різних правових культур, сформованих протягом людської історії, взаємопов'язаних та взаємозалежних. За таких умов правова культура постає як складне й багатовимірне явище культурно-історичного процессу.

Висновки. Правова культура має історичний вимір, відображує в собі досвід життєдіяльності людства, сформований за допомогою діяльності людини та соціуму, поєднанню зовнішнього та внутрішнього факторів її формування (зовнішній - суспільство, внутрішній - людина, ії внутрішній, індивідуальний досвід, самореалізація). Зокрема, людина через свою діяльність впливає на систему соціально-правових відносин, а соціум так само вбирає в себе все найкраще, акумулюючи досвід та формуючи систему соціально-правових відносин у суспільстві, передаючи напрацьовані норми та правила поведінки наступним поколінням.

Розвиток правової культури безпосередньо пов'язаний із загальним рівнем культури, світоглядними домінантами, сформованому у суспільстві менталітеті, масовій одноманітній поведінці людей, діалозі культур та народів, запозиченням у різних правових культур нового та перспективного. Правова культура має перспективи в суспільстві, в якому продукуються сутнісні необхідні елементи права. Без рівня розвитку культури суспільства, його готовності сприйняти ті чи інші цінності та нормативні настанови $є$ неможливим формування суспільства розвиненої правової культури та побудова правової держави, що є тематикою подальших досліджень.

\section{Jimepamypa}

1. Барсуков А. Ю. Правовой прогресс как юридическая категория: учебное пособие / Под ред. А.В. Малько. Саратов: Изд-во ГОУ ВПО «Саратовская государственная академия права», 2006. 128 с.

2. Боас Ф. Границы сравнительного метода в антропологии. Антология исследований культуры. Т.1. Интерпретация культуры. Санкт-Петербург: Университетская книга, 1997. Серия «Культурология XX век». 728 c.

3. Гусейнов А. И. Право и культура. Государственная службба, 2005. № 6 (38). С. 84-90.

4. Морозова Л. А. Теория государства и права в вопросах и ответах. Второе издание. Москва: ОМЕГАЛ, 2005. $595 \mathrm{c}$.

5. Орлова Э. А. Современная городская культура и человек. Москва : РАН Институт философии : Наука, 1987. 193 с.

214c.

6. Орлова Э.А. Введение в социальную и культурную антропологию. Москва: Изд-во МГИК, 1994. 439.

7. Перов Ю. В. Историческое измерение философии культуры. Вестник МГТУ, том 10, №3, 2007. С.

8. Семитко А. П. Развитие правовой культуры как правовой прогресс. Екатеринбург: Изд-во Уральского гос. ун-та, 1996. $312 \mathrm{c.}$

9. Синюкова Т. В. Правовая культура: понятие, структура, соотношение национального и общечеловеческого. Правовая культура, № 2(7), 2009. С. 6-17.

10. Терешкович П. В. Антропология культурная. Новейший философский словарь : Энцикклопедия / Сост. А. А. Грицанов. Минск, 1998. С. 896.

11. Шейко В. М. Формування основ культурології в добу цивілізаційної глобалізації (друга половина XIX - початок XXI ст.) : моногр. Київ: Генеза, 2005. 592 с.

12. Hundt M. Anthropologium de hominis dignitate, natura et proprietatibus, de elementis, partibus et membris humani corporis. Leipzig, 1501. 